\title{
Non-random mating in the two-spot ladybird (Adalia bipunctata): I. A reassessment of the evidence
}

\author{
P. W. E. Kearns, ${ }^{*} \ddagger$ \\ I. P. M. Tomlinson, ${ }^{*}$ \\ P. O'Donald* and \\ C. J. Veltmant
}

\author{
* Department of Genetics, University of Cambridge, \\ Downing Street, Cambridge CB2 3EH, U.K. \\ $\dagger$ Department of Botany and Zoology, Massey \\ University, Palmerston North, New Zealand.
}

\begin{abstract}
There is contradictory evidence concerning non-random mating among melanic and non-melanic phenotypes of Adalia bipunctata. Although most studies have found a mating advantage in favour of melanic individuals, one found random mating. Furthermore, in some samples the melanic mating advantage was frequency-dependent though not in others. In one population males alone gained a frequency-dependent mating advantage, and it has been argued that this is a result of a female sexual preference. There is no direct evidence for mate choice from any other population. In any case, melanic individuals of both sexes often gain a mating advantage so if mate choice is relevant, then these populations must contain "choosy" males as well as "choosy" females. Some of these apparent contradictions are explained by insufficient sampling and/or unsatisfactory statistical analysis. Nevertheless, populations are clearly different from one another and this is important when considering the nature of the melanic mating advantage.
\end{abstract}

\section{INTRODUCTION}

The two spot ladybird, Adalia bipunctata, is a visibly polymorphic beetle, common throughout Europe. It varies in colour and pattern, most obviously on the elytra and pronotum. Most phenotypes can be readily classified as melanic or non-melanic. The commonest melanics are quadrimaculata and sexpustulata, which have black elytra with four and six red spots respectively. The most abundant non-melanic phenotype, typica, has red elytra with two black spots. The remaining non-melanics form a heterogeneous group in which most individuals resemble typica with additional spots or bands. They have been variously classified (e.g. Mader, 1926-37; Lus, 1928; 1932). Often, they are grouped together for convenience as the form annulata (Creed, 1966; Majerus et al., 1982a).

Lus $(1928,1932)$ was the first to work on the genetics of this polymorphism, which he explained in terms of multiple alleles at a single locus. Although some of his conclusions do not apply to all populations, his observation that the melanic

$\ddagger$ Address for reprints: Department of the Environment, Romney House, 43 Marsham Street, London SW1P 3PY. phenotypes, quadrimaculata and sexpustulata, are dominant to non-melanics, is true of all populations studied thus far.

There have been a number of measurements of the distribution of melanic phenotypes in natural populations (Creed, 1966, 1971; Bengston and Hagen, 1975; Scali and Creed, 1975; Bishop et al., 1978). In analysing these surveys, Muggleton (1978) points out that high melanic frequencies are characteristic of populations from the climatic extremes of the species range. But he argues that no single factor will explain the observed distribution of melanism. A selective agent important in one locality may be of little relevance in another.

A factor that does seem of major importance is the more efficient absorption of solar energy by melanics, probably leading to relatively greater activity (Lusis, 1961; Muggleton et al., 1975). A suggestion that melanics are more resistant to atmospheric pollution seems less plausible (Creed, $1971 ; 1975)$. Other factors may include differential predation between phenotypes; indeed, it has even been suggested that ladybirds form an assemblage of Müllerian mimics (Rothschild, 1961; Muggleton, 1978; Brakefield, 1985). But as O'Donald and Muggleton (1979) point out, these putative selective factors do not necessarily give rise to the 
balance of forces required to maintain the polymorphism. On the other hand, they suggested that frequency-dependent non-random mating would be sufficient to maintain the stability of the polymorphism.

Lusis (1961) was the first to suggest that melanic and non-melanic phenotypes mate non-randomly. $\mathrm{He}$ found an excess of melanics in mating pairs, when compared with the population as a whole, and thought that this might be explained by a greater activity of the melanics in sunlight. He pointed out that this could explain the increase in melanic frequency found during the summer months in Berlin by Timofeeff-Ressovsky, (1940). Creed (1975), however, found no evidence of nonrandom mating in data he collected from Britain and Western Europe, or when he analysed data collected by Meissner $(1907 a, b, 1909)$ from Potsdam. But the analyses performed by Lusis and Creed were considered unsatisfactory by Muggleton (1979). He analysed Lusis and Meissner's data as well as some of his own, finding evidence of a two-sided frequency-dependent mating advantage.

It is clear that these various studies of nonrandom mating observed different phenomena, which would have different selective consequences. Creed (1975) alone obtained no evidence of non-random mating. Lusis, (1961) and in a later study Brakefield (1984), each observed an excess of melanic phenotypes of both sexes. A general mating advantage to melanics would produce fixation of one of the melanic phenotypes, so some additional selective force would be required to maintain the polymorphism. But Muggleton's frequency-dependent mating advantage could be sufficient to maintain the polymorphism (O'Donald and Muggleton, 1979), for it is the rarer phenotype, and not just melanic individuals alone, which would gain a mating advantage. A two-sided frequency-dependence such as this is an inevitable outcome of the expression of preference for each phenotype: each gains the advantage when rare and loses it when common.

In contrast, large samples from a British population at Keele, Staffordshire (Majerus et al., 1982a; O'Donald et al., 1984), showed an excess of melanic males only in mating pairs, with no comparable excess of melanic females. Experiments with laboratory populations produced evidence of preferential mating by females in favour of melanic males. If females prefer to mate with specific phenotypes, frequency-dependent mating would then be an inevitable consequence in a polygynous population. Preferred individuals are certain to mate more frequently when they are rare, because a relatively greater proportion of females prefer to mate with them. Frequencydependence has been demonstrated in laboratory populations of Keele ladybirds by observing matings at different phenotypic frequencies (Majerus et al., 1982a; O'Donald and Majerus, 1988); melanic males have the greatest mating advantage at the lowest melanic frequencies.

A female preference for non-melanic phenotypes has not been demonstrated experimentally in samples from the Keele population. Nevertheless, a polymorphism can still be maintained if the frequency-dependence is balanced by natural selection against the melanic phenotype, provided of course that the mating advantage is greater than the adverse selection at low frequencies (O'Donald and Muggleton, 1979). No such selective factor has yet been demonstrated.

Although the differences in the results of these various studies may reflect real differences between populations, it is also possible that the way in which the data were analysed and interpreted contributed to apparent differences between the results. This seems quite possible, given that some of Muggleton's data, as well as some of Creed's came from English populations, several quite close to Keele. Consequently, we have reanalysed data from each of these studies, so they can be compared for evidence of non-random mating.

\section{SOME DEFINITIONS}

To avoid confusion, we shall define some terms we wish to use.

Non-random mating in A. bipunctata can arise for three main reasons; (1) Mating preferences for specific phenotypes (non-assorting preferences); (2) Mating preferences for similar phenotypes (assortative mating), due to assorting preferences; (3) Mating after differential habitat selection, or differential response to climatic factors.

Some authors have regarded preferential assortative mating as being separate from sexual selection (Karlin and O'Donald, 1978; O'Donald, 1980). We regard both assorting and non-assorting preferences as components of sexual selection, albeit separate and often distinguishable. Differential habitat selection, or differential response to climatic factors, does not necessarily involve any mate choice, and is not sexual selection. An example is Lusis's (1961) suggestion that melanic 
ladybirds have a mating advantage because they are more active under specific conditions.

\section{ANALYSIS OF DATA}

All of the studies of non-random mating in $A$. bipunctata have involved difficulties of statistical analysis. Both Creed (1975) and Lusis (1961) were criticised by Muggleton (1979) because they combined heterogeneous samples, which is not only statistically illegitimate, but might also mask any frequency-dependent mating advantage. In addition, the analyses of $\chi^{2}$ were not strictly legitimate because 'expected' mating frequencies were also based on samples which were themselves subject to sampling error. Despite this, we have decided to include similar analyses ourselves which, with appropriate caution, can be useful. Muggleton makes the point (personal communication from O'Donald to Muggleton, 1979) that in the analyses of Lusis and Creed, non-random mating within the mating individuals (that is, assortative mating), may have been confounded with a relative excess of one phenotype in mating pairs. It is desirable, in other words, to separate these two components of mating advantage.

Creed (1975) calculated a term $d$, "the relative deficiency of red [typical phenotypes]". This is given as $(\operatorname{Re}-R o) /(\operatorname{Re} B o)$ where $R$ and $B$ are the numbers of red (typical) and black (melanic) individuals respectively, and $e$ and $o$ are the expected and observed numbers in mating pairs. But this does not seem as useful, as a means of measuring mating success, as the cross product ratio (CPR), first used for A. bipunctata data by Muggleton (1979). The CPR is given by

Total no. of non-melanics

Total no. of melanics

$$
\times \frac{\text { No. of melanics mating }}{\text { No. of non-melanics mating }}
$$

Clearly, this is a measure of mating advantage because a value of CPR greater than 1 indicates an excess of melanics in mating pairs, and a value of less than 1 indicates an excess of non-melanics.

However, we prefer $\mathrm{R}$ given by

Frequency of melanics in mating pairs

Total frequency of melanics

in other words, the mean number of matings a melanic individual obtains, relative to the frequency of melanics in the population as a whole.
The relationship between CPR and $R$ is illustrated by the following:-

$$
\begin{aligned}
\mathrm{CPR} & =\frac{\mathrm{R} \times \text { frequency of non-melanics in sample }}{\text { frequency of non-melanics mating }} \\
& =\mathrm{R} / \mathrm{R}^{\prime}
\end{aligned}
$$

where $\mathrm{R}^{\prime}$ is the corresponding mating advantage to typicals. $R$ and $R^{\prime}$ represent absolute mating advantages of the two phenotypes. CPR represents one of these measures relative to the other. Frequency-dependent expression of preference will give strong frequency-dependence in the values of $R$ and $R^{\prime}$ while their ratio, CPR, may be almost constant. For example, under some models of preference we do not expect CPR to rise or fall monotonically with changes in melanic frequency. As a measure of frequency-dependence $R$ is much more valuable as CPR can give a false impression of how a mating advantage depends on phenotype frequency.

An illustration of the difference in behaviour of CPR and $R$ is shown in table 7 below. Consider the values of CPR and $R$ for males. The highest value for $C P R$ occurs when the frequency of melanics is intermediate at 50 per cent, but the value of $R$ increases as the frequency of melanics declines.

\section{THE EVIDENCE FOR NON-RANDOM MATING}

Meissner (1907 $a, b$ and 1909) sampled mating pairs of $A$. bipunctata on daily collections in Potsdam. His data, which were used in analyses by both Creed (1975) and Muggleton (1979), are shown in table 1 . We have grouped the data for each year, though this may consist of individuals sampled more than once on separate days. In any case, no year's data quite reaches a significant deviation from random mating, though there is a tendency, more pronounced in males, towards an excess of melanics in mating pairs.

Lusis's (1961) data were obtained when he sampled phenotypic frequencies in different "propagation colonies" in Moscow and Riga. As he collected his data he noted the number and phenotypes of mating individuals, but apparently without removing mating pairs from the population. Some individuals could, therefore, have been sampled more than once. The data from his samples, some of which were small, are shown in table 2. There is clear evidence for non-random mating in many of the samples, but there is much heterogeneity as reflected in the $R$ values. Some 
Table 1 Field mating data collected by Meissner. " $t$ " refers to the typical morph and " $m$ " to the melanic morph; females are shown first. Below the observed numbers of mating pairs are the expected numbers calculated from the percentages of " $t$ " and " $m$ " in the population, assuming that there are no differences in the distribution of the sexes between the two morphs. The $\chi^{2}$ values shown represent the totals for non-random mating (n-r) and for assortative mating (asst.), corrected, if necessary, for sample size. In this table, $\mathrm{R}$ is calculated for both sexes together

\begin{tabular}{|c|c|c|c|c|c|c|c|c|c|}
\hline \multirow[b]{2}{*}{ Date } & \multirow{2}{*}{$\begin{array}{l}\% \mathrm{t} \text { in } \\
\text { popln. }\end{array}$} & & \multicolumn{4}{|c|}{ Mating pairs } & \multirow{2}{*}{$\begin{array}{l}x^{2} \\
\mathrm{n}-\mathrm{r}\end{array}$} & \multirow{2}{*}{$\begin{array}{l}\chi^{2} \\
\text { asst. }\end{array}$} & \multirow[b]{2}{*}{$\mathrm{R}$} \\
\hline & & & $t \times t$ & $\mathrm{t} \times \mathrm{m}$ & $\mathrm{m} \times \mathrm{t}$ & $\mathrm{m} \times \mathrm{m}$ & & & \\
\hline 1906 & $58 \cdot 2$ & $\begin{array}{l}\mathrm{O} \\
\mathrm{E}\end{array}$ & $\begin{array}{l}23 \\
23 \cdot 3\end{array}$ & & & $\begin{array}{l}15 \\
12 \cdot 1\end{array}$ & $\begin{array}{l}0.90 \\
\text { ns }\end{array}$ & $\begin{array}{l}0 \cdot 55 \\
\mathrm{~ns}\end{array}$ & $1 \cdot 06$ \\
\hline 1907 & $59 \cdot 1$ & $\begin{array}{l}\mathrm{O} \\
\mathrm{E}\end{array}$ & $\begin{array}{l}26 \\
29 \cdot 3\end{array}$ & $\begin{array}{l}18 \\
20 \cdot 3\end{array}$ & $\begin{array}{l}20 \\
20 \cdot 3\end{array}$ & $\begin{array}{l}20 \\
14 \cdot 1\end{array}$ & $\begin{array}{l}3 \cdot 11 \\
\mathrm{~ns}\end{array}$ & $\begin{array}{l}0.70 \\
\text { ns }\end{array}$ & $1 \cdot 14$ \\
\hline 1908 & $60 \cdot 3$ & $\begin{array}{l}\mathrm{O} \\
\mathrm{E}\end{array}$ & $\begin{array}{l}11 \\
14.9\end{array}$ & $\begin{array}{l}8 \\
9 \cdot 8\end{array}$ & $\begin{array}{l}13 \\
9 \cdot 8\end{array}$ & $\begin{array}{l}9 \\
6.5\end{array}$ & $\begin{array}{l}3 \cdot 36 \\
\text { ns }\end{array}$ & $\begin{array}{l}0.00 \\
\text { ns }\end{array}$ & $1 \cdot 20$ \\
\hline
\end{tabular}

contained an excess of melanics of both sexes, others of only one sex and in some, there was random mating. In no sample was there a significant excess of the typical phenotype in mating pairs, and there was no evidence of assortative mating.

Creed (1975) combined his samples of $A$. bipunctata matings which he collected over several years and these are shown in table 3 . The only distinction he made was of those samples collected in Britain and those in Western Europe. These two categories are bound to contain substantial heterogeneity as they are small samples collected from numerous populations, over several years. In any case, there is no evidence of non-random mating in Creed's data.

Table 2 Field mating data collected by Lusis. Notation as used in table 1, except that "** shows significance at 5 per cent (1-tailed), "**" at 1 per cent and "***" at $0 \cdot 1$ per cent. The upper value of $\mathrm{R}$ is that for melanic females, the lower value, for melanic males. Note that some of the cells (marked + ) have artificially-inflated $\chi^{2}$ values owing to the small expected number of $\mathrm{m} \times \mathrm{m}$ matings

\begin{tabular}{|c|c|c|c|c|c|c|c|c|c|}
\hline \multirow{2}{*}{$\begin{array}{l}\text { Location } \\
\text { and date }\end{array}$} & \multirow{2}{*}{$\begin{array}{l}\% \mathrm{t} \text { in } \\
\text { popln. }\end{array}$} & & \multicolumn{4}{|c|}{ Mating pairs } & \multirow{2}{*}{$\begin{array}{l}x^{2} \\
\mathrm{n}-\mathrm{r}\end{array}$} & \multirow{2}{*}{$\begin{array}{l}\chi^{2} \\
\text { asst. }\end{array}$} & \multirow[b]{2}{*}{$\mathrm{R}$} \\
\hline & & & $t \times t$ & $\mathrm{t} \times \mathrm{m}$ & $\mathrm{m} \times \mathrm{t}$ & $\mathrm{m} \times \mathrm{m}$ & & & \\
\hline Moscow & \multirow[t]{2}{*}{$90 \cdot 5$} & $\mathrm{O}$ & 38 & 5 & 11 & 3 & $16 \cdot 9$ & 0.44 & $2 \cdot 6$ \\
\hline 1948 & & $\mathrm{E}$ & $46 \cdot 7$ & $4 \cdot 9$ & 4.9 & 0.5 & $* * *+$ & ns & $1 \cdot 5$ \\
\hline Moscow & \multirow[t]{2}{*}{$89 \cdot 5$} & $\mathrm{O}$ & 130 & 24 & 24 & 4 & $8 \cdot 38$ & 0.02 & $1 \cdot 5$ \\
\hline 1948 & & $\mathrm{E}$ & $145 \cdot 8$ & $17 \cdot 1$ & $17 \cdot 1$ & $2 \cdot 0$ & $* *$ & ns & $1 \cdot 5$ \\
\hline Moscow & \multirow[t]{2}{*}{$96 \cdot 5$} & $\mathrm{O}$ & 105 & 7 & 10 & 2 & $22 \cdot 9$ & 0.74 & $2 \cdot 7$ \\
\hline 1948 & & $\mathrm{E}$ & $115 \cdot 5$ & $4 \cdot 2$ & $4 \cdot 2$ & $0 \cdot 2$ & $* * *+$ & ns & $2 \cdot 1$ \\
\hline Riga & \multirow[t]{2}{*}{$70 \cdot 7$} & $\mathrm{O}$ & 12 & 6 & 6 & 6 & 3.93 & 0.64 & $1 \cdot 4$ \\
\hline 1949 & & $E$ & $15 \cdot 0$ & $6 \cdot 2$ & $6 \cdot 2$ & $2 \cdot 6$ & $*$ & ns & $1 \cdot 4$ \\
\hline Riga & \multirow[t]{2}{*}{$59 \cdot 3$} & $\mathrm{O}$ & 19 & 10 & 12 & 13 & $2 \cdot 63$ & $1 \cdot 68$ & $1 \cdot 1$ \\
\hline 1950 & & $\mathrm{E}$ & $19 \cdot 0$ & $13 \cdot 0$ & $13 \cdot 0$ & $8 \cdot 9$ & ns & ns & $1 \cdot 0$ \\
\hline Riga & \multirow[t]{2}{*}{$55 \cdot 8$} & $\mathrm{O}$ & 75 & 73 & 71 & 82 & $13 \cdot 1$ & 0.55 & $1 \cdot 2$ \\
\hline 1950 & & E & $93 \cdot 7$ & $74 \cdot 2$ & $74 \cdot 2$ & $58 \cdot 8$ & $* * *$ & ns & $1 \cdot 2$ \\
\hline Riga & \multirow[t]{2}{*}{$61 \cdot 7$} & $\mathrm{O}$ & 14 & 7 & 12 & 6 & $1 \cdot 44$ & 0.00 & $1 \cdot 2$ \\
\hline 1950 & & $\mathrm{E}$ & $14 \cdot 8$ & $9 \cdot 2$ & $9 \cdot 2$ & $5 \cdot 7$ & ns & $\mathrm{ns}$ & 0.9 \\
\hline Riga & \multirow[t]{2}{*}{$63 \cdot 2$} & $\mathrm{O}$ & 82 & 56 & 56 & 34 & $1 \cdot 55$ & $0 \cdot 18$ & $1 \cdot 1$ \\
\hline 1959 & & $\mathrm{E}$ & $89 \cdot 9$ & $52 \cdot 3$ & $52 \cdot 3$ & $30 \cdot 5$ & $\mathrm{~ns}$ & $\mathrm{~ns}$ & $1 \cdot 1$ \\
\hline Riga & \multirow[t]{2}{*}{$63 \cdot 2$} & $\mathrm{O}$ & 268 & 177 & 214 & 136 & $20 \cdot 1$ & 0.07 & $1 \cdot 2$ \\
\hline 1960 & & $\mathrm{E}$ & 317 & 184 & 184 & 107 & $* * *$ & ns & $1 \cdot 1$ \\
\hline Riga & \multirow[t]{2}{*}{$58 \cdot 0$} & $\mathrm{O}$ & 390 & 342 & 305 & 294 & $24 \cdot 5$ & 0.74 & $1 \cdot 1$ \\
\hline 1961 & & $\mathrm{E}$ & 448 & 324 & 324 & 235 & $* * *$ & ns & $1 \cdot 1$ \\
\hline
\end{tabular}


Table 3 Field mating data collected by Creed. Notation as table 1

\begin{tabular}{|c|c|c|c|c|c|c|c|}
\hline \multirow[b]{2}{*}{ Location } & \multirow{2}{*}{$\begin{array}{l}\% \mathrm{t} \text { in } \\
\text { popln. }\end{array}$} & & \multicolumn{3}{|c|}{ Mating pairs } & \multirow{2}{*}{$\begin{array}{l}\chi^{2} \\
\mathrm{n}-\mathrm{r}\end{array}$} & \multirow[b]{2}{*}{$\mathbf{R}$} \\
\hline & & & $t \times t$ & $\mathrm{t} \times \mathrm{m} \& \mathrm{~m} \times \mathrm{t}$ & $\mathrm{m} \times \mathrm{m}$ & & \\
\hline Western & $58 \cdot 7$ & $\mathrm{O}$ & 16 & 16 & 11 & 0.61 & 1.00 \\
\hline Europe & & $\mathrm{E}$ & $14 \cdot 8$ & $18 \cdot 5$ & $9 \cdot 7$ & ns & \\
\hline Great & $84 \cdot 9$ & $\mathrm{O}$ & 111 & 44 & 5 & $1 \cdot 14$ & 1.06 \\
\hline Britain & & $\mathrm{E}$ & $115 \cdot 2$ & $38 \cdot 6$ & $6 \cdot 2$ & $\mathrm{~ns}$ & \\
\hline
\end{tabular}

More recently, Brakefield (1984) obtained large samples from a number of sites in Holland. Some data from his larger samples are shown in table 4. An excess of melanics of both sexes in mating pairs appeared in some samples, but not in others. No assortative mating was found.

Muggleton (1979) used the data from some of the above studies (Meissner, 1907a, b, 1909; Lusis, 1961; Creed, 1975), as well as some of his own, in a thorough analysis of non-random mating. He first analysed the samples for assortative mating, then he compared the distribution of melanic and typica morphs in mating and non-mating individuals in a $2 \times 2$ analysis of $\chi^{2}$. To carry out these analyses it is necessary to combine small samples. This he did, by combining those of similar phenotypic frequencies. He carried out another analysis to overcome the problems of combining samples, enabling each sample to be evaluated separately. He calculated a regression of the

Table 4 Field mating data collected by Brakefield (1984). The notation as tables 1 and 2. N.B. CPR value is always more extreme than the $R$ value by some variable factor dependent on morph frequency. "Sample number" is taken from Brakefield's appendix (1984)

\begin{tabular}{|c|c|c|c|c|c|c|c|c|c|}
\hline \multirow{2}{*}{$\begin{array}{l}\text { Sample } \\
\text { number }\end{array}$} & \multirow{2}{*}{$\begin{array}{l}\% \mathrm{t} \text { in } \\
\text { popln. }\end{array}$} & & \multicolumn{4}{|c|}{ Mating pairs } & \multirow{2}{*}{$\begin{array}{l}\chi^{2} \\
n-r\end{array}$} & \multirow[b]{2}{*}{$\mathbf{R}$} & \multirow[b]{2}{*}{ CPR } \\
\hline & & & $t \times t$ & $\mathrm{t} \times \mathrm{m}$ & $\mathrm{m} \times \mathrm{t}$ & $\mathrm{m} \times \mathrm{m}$ & & & \\
\hline 10 & $80 \cdot 7$ & $\begin{array}{l}\mathrm{O} \\
\mathrm{E}\end{array}$ & $\begin{array}{l}40 \\
41 \cdot 7\end{array}$ & $\begin{array}{c}9 \\
10 \cdot 0\end{array}$ & $\begin{array}{l}13 \\
10 \cdot 0\end{array}$ & $\begin{array}{l}2 \\
2 \cdot 4\end{array}$ & $\begin{array}{l}1.09 \\
\text { ns }\end{array}$ & $\begin{array}{l}1 \cdot 21 \\
0 \cdot 89\end{array}$ & $\begin{array}{l}1.28 \\
0.87\end{array}$ \\
\hline 12 & $77 \cdot 6$ & $\begin{array}{l}\mathrm{O} \\
\mathrm{E}\end{array}$ & $\begin{array}{l}122 \\
118 \cdot 0\end{array}$ & $\begin{array}{l}33 \\
34 \cdot 1\end{array}$ & $\begin{array}{l}27 \\
34 \cdot 1\end{array}$ & $\begin{array}{l}14 \\
9 \cdot 8\end{array}$ & $\begin{array}{l}3 \cdot 39 \\
\text { ns }\end{array}$ & $\begin{array}{l}0.93 \\
1 \cdot 07\end{array}$ & $\begin{array}{l}0.92 \\
1.09\end{array}$ \\
\hline 23 & $91 \cdot 0$ & $\begin{array}{l}\mathrm{O} \\
\mathrm{E}\end{array}$ & $\begin{array}{l}421 \\
427 \cdot 3\end{array}$ & $\begin{array}{l}47 \\
42 \cdot 3\end{array}$ & $\begin{array}{l}45 \\
42 \cdot 3\end{array}$ & $\begin{array}{l}3 \\
4 \cdot 2\end{array}$ & $\begin{array}{l}0.91 \\
\text { ns }\end{array}$ & $\begin{array}{l}1.03 \\
1.08\end{array}$ & $\begin{array}{l}1.04 \\
1.08\end{array}$ \\
\hline 25 & $75 \cdot 4$ & $\begin{array}{l}\mathrm{O} \\
\mathrm{E}\end{array}$ & $\begin{array}{l}287 \\
312 \cdot 1\end{array}$ & $\begin{array}{l}106 \\
101 \cdot 8\end{array}$ & $\begin{array}{l}123 \\
101 \cdot 8\end{array}$ & $\begin{array}{l}33 \\
33 \cdot 2\end{array}$ & $\begin{array}{l}6 \cdot 59 \\
*\end{array}$ & $\begin{array}{l}1 \cdot 16 \\
1 \cdot 03\end{array}$ & $\begin{array}{l}1 \cdot 22 \\
1 \cdot 04\end{array}$ \\
\hline 28 & $58 \cdot 0$ & $\begin{array}{l}\mathrm{O} \\
\mathrm{E}\end{array}$ & $\begin{array}{l}46 \\
43 \cdot 1\end{array}$ & $\begin{array}{l}30 \\
31 \cdot 2\end{array}$ & $\begin{array}{l}34 \\
31 \cdot 2\end{array}$ & $\begin{array}{l}18 \\
22 \cdot 6\end{array}$ & $\begin{array}{l}1 \cdot 43 \\
\mathrm{~ns}\end{array}$ & $\begin{array}{l}0.97 \\
0.89\end{array}$ & $\begin{array}{l}0.94 \\
0.83\end{array}$ \\
\hline 31 & $48 \cdot 8$ & $\begin{array}{l}\mathrm{O} \\
\mathrm{E}\end{array}$ & $\begin{array}{l}37 \\
55 \cdot 0\end{array}$ & $\begin{array}{l}64 \\
57 \cdot 7\end{array}$ & $\begin{array}{l}62 \\
57 \cdot 7\end{array}$ & $\begin{array}{l}68 \\
60 \cdot 6\end{array}$ & $\begin{array}{l}7 \cdot 81 \\
* *\end{array}$ & $\begin{array}{l}1 \cdot 10 \\
1 \cdot 12\end{array}$ & $\begin{array}{l}1 \cdot 23 \\
1 \cdot 27\end{array}$ \\
\hline 32 & $55 \cdot 2$ & $\begin{array}{l}\mathrm{O} \\
\mathrm{E}\end{array}$ & $\begin{array}{l}218 \\
255 \cdot 6\end{array}$ & $\begin{array}{l}209 \\
207 \cdot 5\end{array}$ & $\begin{array}{l}205 \\
207 \cdot 5\end{array}$ & $\begin{array}{l}207 \\
168 \cdot 4\end{array}$ & $\begin{array}{l}14 \cdot 4 \\
* * *\end{array}$ & $\begin{array}{l}1 \cdot 10 \\
1 \cdot 11\end{array}$ & $\begin{array}{l}1 \cdot 19 \\
1 \cdot 21\end{array}$ \\
\hline 33 & $51 \cdot 8$ & $\begin{array}{l}\mathrm{O} \\
\mathrm{E}\end{array}$ & $\begin{array}{l}29 \\
23 \cdot 6\end{array}$ & $\begin{array}{l}21 \\
22 \cdot 0\end{array}$ & $\begin{array}{l}18 \\
22 \cdot 0\end{array}$ & $\begin{array}{l}20 \\
20 \cdot 4\end{array}$ & $\begin{array}{l}2 \cdot 00 \\
\mathrm{~ns}\end{array}$ & $\begin{array}{l}0.90 \\
0.97\end{array}$ & $\begin{array}{l}0 \cdot 82 \\
0.94\end{array}$ \\
\hline 36 & $46 \cdot 1$ & $\begin{array}{l}\mathrm{O} \\
\mathrm{E}\end{array}$ & $\begin{array}{l}7 \\
6 \cdot 0\end{array}$ & $\begin{array}{l}7 \\
7 \cdot 0\end{array}$ & $\begin{array}{l}5 \\
7 \cdot 0\end{array}$ & $\begin{array}{l}9 \\
8 \cdot 1\end{array}$ & $\begin{array}{l}0 \cdot 83 \\
\text { ns }\end{array}$ & $\begin{array}{l}0.93 \\
1.06\end{array}$ & $\begin{array}{l}0 \cdot 86 \\
1 \cdot 14\end{array}$ \\
\hline 37 & $48 \cdot 5$ & $\begin{array}{l}\mathrm{O} \\
\mathrm{E}\end{array}$ & $\begin{array}{l}5 \\
8 \cdot 2\end{array}$ & $\begin{array}{l}7 \\
8 \cdot 7\end{array}$ & $\begin{array}{l}13 \\
8 \cdot 7\end{array}$ & $\begin{array}{l}10 \\
9 \cdot 3\end{array}$ & $\begin{array}{l}3 \cdot 75 \\
\text { ns }\end{array}$ & $\begin{array}{l}1 \cdot 28 \\
0 \cdot 94\end{array}$ & $\begin{array}{l}1 \cdot 81 \\
0 \cdot 89\end{array}$ \\
\hline 38 & $45 \cdot 5$ & $\begin{array}{l}\mathrm{O} \\
\mathrm{E}\end{array}$ & $\begin{array}{l}104 \\
124 \cdot 8\end{array}$ & $\begin{array}{l}177 \\
149 \cdot 5\end{array}$ & $\begin{array}{l}150 \\
149 \cdot 5\end{array}$ & $\begin{array}{l}172 \\
179 \cdot 1\end{array}$ & $\begin{array}{l}8 \cdot 81 \\
* *\end{array}$ & $\begin{array}{l}0.98 \\
1.06\end{array}$ & $\begin{array}{l}0.96 \\
1 \cdot 15\end{array}$ \\
\hline 54 & $77 \cdot 8$ & $\begin{array}{l}\mathrm{O} \\
\mathrm{E}\end{array}$ & $\begin{array}{l}14 \\
18 \cdot 2\end{array}$ & $\begin{array}{l}7 \\
5 \cdot 2\end{array}$ & $\begin{array}{l}5 \\
5 \cdot 2\end{array}$ & $\begin{array}{l}4 \\
1 \cdot 5\end{array}$ & $\begin{array}{l}4 \cdot 36 \\
*\end{array}$ & $\begin{array}{l}1.35 \\
1.65\end{array}$ & $\begin{array}{l}1 \cdot 50 \\
2 \cdot 03\end{array}$ \\
\hline
\end{tabular}


natural $\log$ of the CPR on the arcsine transform of the melanic frequency, including all but a few of the samples. Higher CPR correlated with lower frequency. This showed that the mating advantage of melanics was negatively frequency-dependent, a result consistent with the expression of a male and/or female mating preference (O'Donald and Muggleton, 1979). But there are two problems with this approach. First, since the CPR itself depends on phenotypic frequency the technique is not strictly justifiable. Second, four key data points in Muggleton's analysis, at which melanic frequency was highest, consisted of only 18 mating pairs (Brakefield, 1984). Some samples, in other words, were more important than others.

We have carried out regression analyses using values of $R$ or CPR and the frequency of melanics in the population, from the separate and combined data of Lusis (1961), Muggleton (1979 and Ph.D. Thesis) and Brakefield (1984). In this way, we can measure the effects of a negative frequency-dependence in each sample, as well as in combined samples. We have not included Meissner's data (1907a, $b, 1909)$ which consist of a number of small non-independent samples. Our analyses suffer from the problem that samples are likely to be heterogeneous, and their sizes vary from tens to hundreds. But we have tried to avoid one possible source of error which was in Muggleton's analysis, that is, we have only included data from samples with over ten mating pairs. Muggleton excluded a few samples from his analysis which contained no mating melanics. The problem with excluding samples is that it might well introduce bias (Brakefield, 1984); but this was inevitable in Muggleton's case, given the value of the resulting logarithmic transformation. In order to facilitate the comparison with Muggleton's analysis, we decided not to "weight" by sample size.

The results of our regression analyses in table 5 show no evidence for a frequency-dependent mating advantage to melanic individuals in either Muggleton's data, or Brakefield's Dutch data. Only Lusis's data show a significant negative frequency-dependent mating advantage on its own, and this is stronger for females than for males. Table 5 also shows that when Lusis's data is combined with other data, as in Muggleton's analysis, there can be a significant regression. It seems likely that Lusis's data was the sole or at least major cause of the regression in Muggleton's analysis.

Table 5 Results of linear regression analysis on the data of Lusis, Muggleton and Brakefield. In the table, $x$ refers to the arcsine (population frequency of melanics of both sexes) 0.5 and is common to all analyses. $y$ is the natural logarithm of six possible variables: $\mathrm{R}$ calculated for both sexes $\left(R_{t}\right)$; CPR for both sexes $\left(C P R_{t}\right)$; $R$ for females $\left(R_{f}\right)$; $R$ for males $\left(R_{m}\right)$; CPR for females $\left(C P R_{f}\right)$; and $C P R$ for males $\left(C P R_{m}\right)$. Those populations where $R=C P R=0$ are excluded from the analysis. The data sources are: L for Lusis (1961); M for Muggleton (1979 and Ph.D. thesis): and $\mathrm{B}$ for Brakefield (1984). The slope of the regression equation shows whether the mating advantage to melanics is negatively or positively frequency-dependent

\begin{tabular}{|c|c|c|c|c|c|}
\hline Data source & $y$ & Regression equation & $t$ & $\mathrm{df}$ & Significance \\
\hline $\mathrm{L}$ & $\mathrm{R}_{\mathrm{q}}$ & $y=0.910-1 \cdot 176 x$ & $6 \cdot 91$ & 8 & $P<0.001$ \\
\hline $\mathrm{L}$ & $\mathrm{CPR}_{\mathrm{t}}$ & $y=0.976-1.150 x$ & $4 \cdot 79$ & 8 & $P<0.001$ \\
\hline $\mathrm{L}$ & $\mathrm{R}_{\mathrm{f}}$ & $y=1 \cdot 103-1.421 x$ & $5 \cdot 60$ & 8 & $P<0.001$ \\
\hline $\mathrm{L}$ & $\mathrm{R}_{\mathrm{m}}$ & $y=0.666-0.864 x$ & $4 \cdot 59$ & 8 & $P<0.001$ \\
\hline $\mathrm{L}$ & $\mathrm{CPR}_{\mathrm{f}}$ & $y=1 \cdot 200-1.408 x$ & $4 \cdot 25$ & 8 & $P<0.01$ \\
\hline $\mathrm{L}$ & $\mathrm{CPR}_{\mathrm{m}}$ & $y=0.703-0.825 x$ & $2 \cdot 65$ & 8 & $P<0.05$ \\
\hline$M$ & & No significant correlation & & & \\
\hline $\mathrm{B}$ & & No significant correlation & & & \\
\hline $\mathrm{L}, \mathrm{M}$ & & No significant correlation & & & \\
\hline $\mathrm{L}, \mathrm{B}$ & $\mathrm{R}_{\mathrm{t}}$ & $y=0 \cdot 155-0 \cdot 154 x$ & $0 \cdot 52$ & 40 & $P>0.60$ \\
\hline L, B & $\mathrm{CPR}_{1}$ & $y=0.145-0.059 x$ & $0 \cdot 17$ & 40 & $P>0.80$ \\
\hline $\mathrm{L}, \mathrm{B}$ & $\mathrm{R}_{\mathrm{f}}$ & $y=0.588-0.841 x$ & $2 \cdot 81$ & 38 & $P<0.01$ \\
\hline $\mathrm{L}, \mathrm{B}$ & $\mathbf{R}_{\mathrm{m}}$ & $y=0.133-0.087 x$ & $0 \cdot 39$ & 40 & $P>0.60$ \\
\hline $\mathrm{L}, \mathrm{B}$ & $\mathrm{CPR}_{\mathrm{f}}$ & $y=0.654-0.885 x$ & $2 \cdot 28$ & 38 & $P<0.05$ \\
\hline $\mathrm{L}, \mathrm{B}$ & $\mathrm{CPR}_{\mathrm{m}}$ & $y=0.065-0.151 x$ & 0.49 & 40 & $P>0.60$ \\
\hline M, B & & No significant correlation & & & \\
\hline $\mathrm{L}, \mathrm{M}, \mathrm{B}$ & $\mathrm{R}_{\mathrm{t}}$ & $y=0.252-0.286 x$ & $1 \cdot 13$ & 52 & $P>0.20$ \\
\hline $\mathrm{L}, \mathrm{M}, \mathrm{B}$ & $\mathrm{CPR}_{1}$ & $y=0.256-0.208 x$ & 0.72 & 52 & $P>0.40$ \\
\hline $\mathrm{L}, \mathrm{M}, \mathrm{B}$ & $\mathrm{R}_{\mathrm{F}}$ & $y=0.494-0.695 x$ & $2 \cdot 47$ & 48 & $P<0.02$ \\
\hline $\mathrm{L}, \mathrm{M}, \mathrm{B}$ & $\mathrm{R}_{\mathrm{m}}$ & $y=0.351-0.420 x$ & 1.61 & 51 & $P>0.10$ \\
\hline $\mathrm{L}, \mathrm{M}, \mathrm{B}$ & $\mathrm{CPR}_{\mathrm{f}}$ & $y=0.555-0.728 x$ & $2 \cdot 09$ & 48 & $P<0.05$ \\
\hline $\mathrm{L}, \mathrm{M}, \mathrm{B}$ & $\mathrm{CPR}_{\mathrm{m}}$ & $y=0.328-0.248 x$ & 0.75 & 51 & $P>0.40$ \\
\hline
\end{tabular}


Table 6 Results of linear regression analysis to search for correlation between melanic male $\left(R_{m}\right)$ and female $\left(R_{f}\right)$ mating success. Notation as table 5

\begin{tabular}{lllcl}
\hline Data source & Regression equation & $t$ & df & Significance \\
\hline $\mathrm{L}$ & $\mathrm{R}_{\mathrm{m}}=0.033+0.488 \mathrm{R}_{\mathrm{f}}$ & 3.37 & 8 & $P<0.01$ \\
M & $\mathrm{R}_{\mathrm{m}}=0.376-0.740 \mathrm{R}_{\mathrm{f}}$ & $2 \cdot 30$ & 7 & $P>0.05$ \\
B & $\mathrm{R}_{\mathrm{m}}=0.085+0.085 \mathrm{R}_{\mathrm{f}}$ & 0.82 & 28 & $P>0.40$ \\
L, M & $\mathrm{R}_{\mathrm{m}}=0.322-0.410 \mathrm{R}_{\mathrm{f}}$ & 1.85 & 17 & $P>0.05$ \\
L, B & $\mathrm{R}_{\mathrm{m}}=0.103+0.054 \mathrm{R}_{\mathrm{f}}$ & 0.60 & 38 & $P>0.50$ \\
M, B & $\mathrm{R}_{\mathrm{m}}=0.141-0.290 \mathrm{R}_{\mathrm{f}}$ & 2.30 & 37 & $P<0.05$ \\
L, M, B & $\mathrm{R}_{\mathrm{m}}=0.156-0.170 \mathrm{R}_{\mathrm{f}}$ & 1.53 & 47 & $P>0.10$ \\
\hline
\end{tabular}

In an attempt to determine whether a mating advantage is independent of sex we have looked for an association between the mating success of male and female melanics. The results in table 6 show that there is a significant association between the advantage to males and females in Lusis's data, but this is not true of Brakefield's or Muggleton's data.

\section{THE EVIDENCE FOR MATE CHOICE}

It seems then that the best evidence for a negatively frequency-dependent mating advantage to melanics is found in Lusis's (1961) data; and this advantage can be to both males and/or females. These populations are therefore distinctly different from those of Muggleton (1979) and Brakefield (1984). O'Donald and Muggleton (1979) originally suggested that a negatively frequency-dependent mating advantage would result from two-spot ladybirds choosing their mates. They fitted models of mating preferences to the data from Potsdam (Meissner, 1907a, b, 1909) and England (Muggleton, 1979). This was used to give maximum likelihood estimates for mating parameters such as the preference for melanic and non-melanic individuals. Preference was assumed to be expressed by both sexes, because the frequencies of matings of melanics and non-melanics did not differ significantly between the sexes.

Direct evidence of mate choice in A. bipunctata was eventually reported by Majerus et al. (1982a), when working with a British population from Keele, Staffordshire, which was polymorphic for melanic and typical morphs. Three methods were used to measure mating frequencies: (i) preference tests in large population cages measuring $2 \mathrm{~m} \times$ $1 \mathrm{~m} \times 1 \mathrm{~m}$, sited in a greenhouse; (ii) "formal mating tests" in relatively small mating chambers in the laboratory; and (iii) measurement of mating frequencies in the natural population.
The tests in population cages and mating chambers were the first which had been carried out on $A$. bipunctata under experimental conditions. It is necessary to sex the ladybirds for use in such experiments. Although this is a difficult process, success rates of over 96 per cent were claimed for laboratory stocks, and 98 per cent for field samples (because there was less variation in size). Sexing was clearly an important advance because previously, individuals could only be sexed by their position in copuli (Muggleton, 1979; O'Donald and Muggleton, 1979).

The results from the population cage experiments are in table 7. Analysis of $\chi^{2}$ shows that there was an excess of melanics in mating pairs, but only the male excess was significant.

O'Donald et al. (1984) fitted Karlin and O'Donald's (1978) model of encounter-dependent assorting and non-assorting female preferences to the population cage data. Maximum likelihood estimates suggested that about 30 per cent of all females expressed a non-assorting preference for melanic males. This preference would have given rise to the frequency-dependence of the male mating advantage seen in the data. The applicability of the model and the validity of the cage data were thus simultaneously enhanced. It is important, however, not to overestimate how useful model fitting can be. Any model can be made sufficiently complex to fit any set of data, and Majerus et al. noted that their model fitting did no more than illustrate the plausibility of the existence of a polymorphic female preference in the Keele population.

The results from the second experiment of Majerus et al. (1982a), the "formal mating tests", are shown in table 8 . The magnitude of the mating advantage to melanic males in this experiment was entirely consistent with that from the population cage experiments.

The field data collected from Keele by Majerus ot al. (1982a) shows no significant differences in 
Table 7 Some laboratory mating data collected by Majerus et al., (1982a). Notation as tables 1 and 2

\begin{tabular}{|c|c|c|c|c|c|c|c|c|c|}
\hline \multirow{2}{*}{$\begin{array}{l}\% \mathrm{t} \text { in } \\
\text { test }\end{array}$} & & \multicolumn{4}{|c|}{ Mating pairs } & \multirow{2}{*}{$\begin{array}{l}\chi^{2} \\
\text { n-r }\end{array}$} & \multirow{2}{*}{$\begin{array}{l}\chi^{2} \\
\text { asst. }\end{array}$} & \multirow[b]{2}{*}{$\mathbf{R}$} & \multirow[b]{2}{*}{ CPR } \\
\hline & & $t \times t$ & $\mathrm{t} \times \mathrm{m}$ & $\mathrm{m} \times \mathrm{t}$ & $\mathbf{m} \times \mathbf{m}$ & & & & \\
\hline $70 \cdot 0$ & $\begin{array}{l}\mathrm{O} \\
\mathrm{E}\end{array}$ & $\begin{array}{l}27 \\
35 \cdot 8\end{array}$ & $\begin{array}{l}21 \\
15 \cdot 3\end{array}$ & $\begin{array}{l}12 \\
15 \cdot 3\end{array}$ & $\begin{array}{l}13 \\
6.6\end{array}$ & $\begin{array}{l}11 \cdot 3 \\
* * *\end{array}$ & $\begin{array}{l}0.45 \\
\text { ns }\end{array}$ & $\begin{array}{l}1 \cdot 14 \\
1 \cdot 55\end{array}$ & $\begin{array}{l}1.22 \\
2.03\end{array}$ \\
\hline 70.0 & $\begin{array}{l}\mathrm{O} \\
\mathrm{E}\end{array}$ & $\begin{array}{l}34 \\
44 \cdot 6\end{array}$ & $\begin{array}{l}27 \\
19 \cdot 1\end{array}$ & $\begin{array}{l}14 \\
19 \cdot 1\end{array}$ & $\begin{array}{l}16 \\
8 \cdot 2\end{array}$ & $\begin{array}{l}14 \cdot 6 \\
* * *\end{array}$ & $\begin{array}{l}0.66 \\
\mathrm{~ns}\end{array}$ & $\begin{array}{l}1 \cdot 10 \\
1 \cdot 58\end{array}$ & $\begin{array}{l}1 \cdot 15 \\
2 \cdot 09\end{array}$ \\
\hline $50 \cdot 0$ & $\begin{array}{l}\mathrm{O} \\
\mathrm{E}\end{array}$ & $\begin{array}{c}9 \\
15 \cdot 5\end{array}$ & $\begin{array}{l}20 \\
15 \cdot 5\end{array}$ & $\begin{array}{c}9 \\
15 \cdot 5\end{array}$ & $\begin{array}{l}24 \\
15 \cdot 5\end{array}$ & $\begin{array}{l}11 \cdot 4 \\
* * *\end{array}$ & $\begin{array}{l}0.11 \\
\text { ns }\end{array}$ & $\begin{array}{l}1.06 \\
1.42\end{array}$ & $\begin{array}{l}1 \cdot 14 \\
2 \cdot 44\end{array}$ \\
\hline 50.0 & $\begin{array}{l}O \\
\mathrm{E}\end{array}$ & $\begin{array}{c}7 \\
11 \cdot 3\end{array}$ & $\begin{array}{l}13 \\
11 \cdot 3\end{array}$ & $\begin{array}{c}7 \\
11 \cdot 3\end{array}$ & $\begin{array}{l}18 \\
11 \cdot 3\end{array}$ & ${ }_{* *}^{7 \cdot 53}$ & $\begin{array}{l}0.25 \\
\mathrm{~ns}\end{array}$ & $\begin{array}{l}1 \cdot 11 \\
1 \cdot 38\end{array}$ & $\begin{array}{l}1 \cdot 25 \\
2 \cdot 21\end{array}$ \\
\hline 30.0 & $\begin{array}{l}\mathrm{O} \\
\mathrm{E}\end{array}$ & $\begin{array}{c}8 \\
10 \cdot 6\end{array}$ & $\begin{array}{l}24 \\
24 \cdot 8\end{array}$ & $\begin{array}{l}15 \\
24 \cdot 8\end{array}$ & $\begin{array}{l}71 \\
57 \cdot 8\end{array}$ & $\underset{* *}{7 \cdot 54}$ & $\begin{array}{l}0.85 \\
\mathrm{~ns}\end{array}$ & $\begin{array}{l}1 \cdot 04 \\
1 \cdot 15\end{array}$ & $\begin{array}{l}1.15 \\
1.77\end{array}$ \\
\hline $30 \cdot 0$ & $\begin{array}{l}\mathrm{O} \\
\mathrm{E}\end{array}$ & $\begin{array}{l}7 \\
9 \cdot 5\end{array}$ & $\begin{array}{l}27 \\
22 \cdot 3\end{array}$ & $\begin{array}{l}12 \\
22 \cdot 3\end{array}$ & $\begin{array}{l}60 \\
51.9\end{array}$ & $\begin{array}{l}7.67 \\
* *\end{array}$ & $\begin{array}{l}0.24 \\
\text { ns }\end{array}$ & $\begin{array}{l}0.97 \\
1.17\end{array}$ & $\begin{array}{l}0.91 \\
1.96\end{array}$ \\
\hline
\end{tabular}

the distribution of the sexes between the morphs. But there is a significant excess of melanic males in mating pairs. They are involved in 46.2 per cent of matings, compared to their population frequency of 31.7 per cent ( $R$ for females $=1 \cdot 10$, $R$ for males $=1.46, C P R$ for females $=1.16$ and CPR for males $=1 \cdot 85)$. Majerus et al. $(1982 a)$ used these data to derive the estimate that about 21 per cent of females expressed a preference. So there appears to be consistency in the expression of the apparent female preference in population cage experiments, formal mating tests and in mating pairs collected from the wild population.

To show preference was genetic, Majerus et al. $(1982 b)$ selected for female mating preference in a population cage experiment. In each generation they removed eggs from females that had mated with melanic males, thereby attempting to increase the frequency of any alleles for preference. An unselected control line was also maintained. The excess of mating melanic males increased significantly over four generations of selection, while that in the control line was roughly constant.

Subsequently, males and females from the selected line were tested separately against individuals from a standard Keele stock. A mating excess of melanic males was observed only when females were used from the selected line.

An additional field sample of $A$. bipunctata was obtained from the Keele population in 1982 (O'Donald et al., 1984). The results are consistent with those found in 1981 (Majerus et al., 1982a). The frequency of melanic males was 34.4 per cent in the population as a whole, and $49 \cdot 1$ per cent in mating pairs ( $R$ for females $=1 \cdot 04, R$ for males $=$ 1.43, CPR for females $=1.06$ and CPR for males $=$ 1.84). These results were used to obtain the estimate that 20.3 per cent of females expressed a preference, which is very similar to that obtained in the previous population cage experiments and formal mating tests (Majerus et al., 1982a).

In addition, there appeared to be significant assortative mating of the annulata phenotype. Models were fitted to these data allowing for separate genetic control of the annulata phenotype and for its postulated assortative mating preference. Natural selection against the melanic phenotype was also incorporated. The results suggested that the observed frequency of typica could only be maintained if it received a frequency-dependent mating advantage equivalent to a preference of about $0 \cdot 2$. As no such preference has yet been

Table 8 The "formal mating tests" of Majerus et al. (1982a).

\begin{tabular}{|c|c|c|c|c|c|c|c|c|c|}
\hline \multirow{2}{*}{$\begin{array}{l}\% t \text { in } \\
\text { test }\end{array}$} & & \multicolumn{4}{|c|}{ Mating pairs } & \multirow{2}{*}{$\begin{array}{l}\chi^{2} \\
n-r\end{array}$} & \multirow{2}{*}{$\begin{array}{l}\chi^{2} \\
\text { asst. }\end{array}$} & \multirow[b]{2}{*}{$\mathbf{R}$} & \multirow[b]{2}{*}{ CPR } \\
\hline & & $t \times t$ & $t \times m$ & $m \times t$ & $\mathrm{~m} \times \mathrm{m}$ & & & & \\
\hline $50 \cdot 0$ & $\begin{array}{l}\mathrm{O} \\
\mathrm{E}\end{array}$ & $\begin{array}{l}28 \\
35 \cdot 0\end{array}$ & $\begin{array}{l}39 \\
35 \cdot 0\end{array}$ & $\begin{array}{l}26 \\
35 \cdot 0\end{array}$ & $\begin{array}{l}47 \\
35 \cdot 0\end{array}$ & $\begin{array}{l}8 \cdot 29 \\
* *\end{array}$ & $\begin{array}{l}0.56 \\
\mathrm{~ns}\end{array}$ & $\begin{array}{l}1 \cdot 04 \\
1 \cdot 23\end{array}$ & $\begin{array}{l}1.09 \\
1.59\end{array}$ \\
\hline
\end{tabular}


observed, and assuming that the model was valid, then it follows that some form of frequency-dependent natural selection is acting in favour of the typical morph. But no suitable selective force has yet been identified in the Keele population, or indeed, any other population of $A$. bipunctata.

O'Donald and Majerus (1985) tested various polygenic and single locus models against data from the selection lines. The results seemed consistent with the hypothesis that a single locus controlled the female mating preference. This was confirmed in a subsequent experiment (Majerus et al., 1986), in which mating pairs were removed from a line selected for female preference for ten generations. The progeny of each of these mating pairs, referred to as "isofemale lines", were tested for preference in small mating chambers. In summary, these "formal mating tests" used ten females in a perspex container with five melanic and five typical males. At 30 minute intervals, any mating pairs were removed and replaced with others of the same phenotype and sex, so in each 30 minute interval, there was mating without replacement. This was repeated for many additional intervals and the data were summed for each "isofemale line". A general test for significance based on the null hypothesis of no preference showed wide variation between the "isofemale lines". An excess of melanic males was taken as an indication of preference, and a simple model (see Majerus et al, 1986) yielded an estimate $(y)$ of the proportion of females mating preferentially in each "isofemale line".

But there are several problems with this experimental design:

(1) To obtain sufficient data, it was necessary to test each "isofemale line" over many 30 minute intervals. After a mating pair had been removed, they were often returned to the experiment in a subsequent 30 minute interval. In other words, individuals were used several times and this could lead to increased heterogeneity between lines, and bias, when estimating the preference. But there is no satisfactory way of overcoming this problem; it is practically impossible to rear and maintain sufficiently large stocks of ladybirds from individual pairs.

(2) The frequency of mating per 30 minute interval may be an important factor in testing and measuring female preference. This can be a serious problem if a large proportion of individuals have mated after 30 minutes. There is then little opportunity of demonstrating the existence of a preference. Thus, the $\chi^{2}$ test for preference becomes insensitive and the estimate of preference subject to high variance. There was a mean of 2.5 matings per 30 minute interval in the "isofemale line" experiments, but as many as five or six matings took place in some intervals (Majerus et al, 1986).

(3) Because mating pairs alone were replaced every 30 minutes, non-mating individuals could well be left in the chamber over several 30 minute sessions. In consequence, they would contribute to several sets of data, as a single individual would be counted several times as "non-mating" (see contingency table, table 9). This would be a problem if a few injured or immature males were unwilling to mate, as there would be an apparent preference against their phenotype.

Table 9 Form of contingency table used in the analysis of the isofemale lines

\begin{tabular}{llll}
\hline & Melanic males & Typical males & \\
\hline Mating & $n_{1}$ & $n_{2}$ & $m$ \\
Non-mating & $n_{3}$ & $n_{4}$ & $n$ \\
\hline & $n_{\mathrm{Q}}$ & $n_{\mathrm{T}}$ & $\mathrm{N}$ \\
\hline
\end{tabular}

(4) The data collected in the formal mating tests are therefore difficult to analyse. Majerus et al. used a $2 \times 2$ table of the form shown in table 9 , to test the significance of the deviation from random mating in each isofemale line. At the end of each 30-minute interval the phenotypes of the mating and non-mating individuals were noted. They were summed in the contingency table at the end of the experiment.

The $\chi^{2}$ for the $2 \times 2$ table tests for an association between male phenotype and mating status. This test is a close approximation to the exact $\chi^{2}$ test based on hypergeometric sampling, in which a random sample is assumed to be drawn from a finite population consisting of $n_{\mathrm{O}}$ and $n_{\mathrm{T}}$ males. On this null hypothesis, $n_{1}$ has hypergeometric variance $\operatorname{pqm}(N-m) /(N-1)$, where $p$ and $q$ are the probabilities of melanic and typical males in the population. This gives the $\chi^{2}$ test

$$
\chi^{2}=\left(n_{1}-m p\right)^{2} /[m p q(N-m) /(N-1)]
$$

which reduces to

$$
\chi^{2}=\left(n_{1} n_{4}-n_{2} n_{3}\right)^{2}(N-1) /\left[m n_{\mathrm{Q}} n_{\mathrm{T}}(N-m)\right] .
$$

This is identical to the $\chi^{2}$ for the $2 \times 2$ table except that the factor $(N-1)$ is replaced by $N$. The added dimension of the different lines gives rise to a 
$2 \times 2 \times N$ table for $N$ lines. Majerus et al. (1986) tested the differences preference between lines by the interaction terms in the analysis of $\chi^{2}$ for the $2 \times 2 \times N$ table.

These four points above show there were considerable methodological problems in analysing the results of the isofemale line experiment of Majerus et al. (1986), but it is hard to see how these difficulties can be used as a fatal criticism of their general findings, given the preference values of the "isofemale lines" (see table 10). In "high preference lines" most females mate with melanic males.

In addition to the high lines with preferences of over 80 per cent (table 10), three other types of isofemale were found: one type had a high/intermediate preference of 50 to 60 per cent; another had low/intermediate preference of 32 to 44 per cent; and the final type had a low preference of 0 to 1 per cent, in other words, they mated at random.

This distribution of preference was considered to be consistent with the control of a single dominant allele. Suppose that preference is controlled by a single dominant allele (B). Females and males sampled from the selected line to make up the isofemale lines could have had preference genotypes as shown below.

(a) $\mathrm{BB}$ female $\times \mathrm{BB}, \mathrm{Bb}$, bb male

(b) $\mathrm{Bb}$ female $\times \mathrm{BB}$ male

$$
\rightarrow \text { all } F_{1} B \text { phenotype }
$$

$\rightarrow$ all $F_{1} B$ phenotype

$\times \mathrm{Bb}$ male $\rightarrow \frac{3}{4} \mathrm{~F}_{1} \mathrm{~B}, \frac{1}{4} \mathrm{~F}_{1} \mathrm{~b}$

$\times$ bb male $\rightarrow \frac{1}{2} F_{1} B, \frac{1}{2} F_{1} b$

(c) bb female $\times \mathrm{BB}$ male $\rightarrow$ all $\mathrm{F}_{1} \mathrm{~B}$

$\times \mathrm{Bb}$ male $\rightarrow \frac{1}{2} \mathrm{~F}_{1} \mathrm{~B}, \frac{1}{2} \mathrm{~F}_{1} \mathrm{~b}$

$\times$ bb male $\rightarrow$ all $F_{1} b$.

If this interpretation were true, then each "isofemale line" would produce an $F_{1}$ with either one of four possible frequencies of preference: all " $\mathrm{B}$ "; $\frac{3}{4} \mathrm{~B} ; \frac{1}{2} \mathrm{~B}$; or all b. This agreed with the four preference categories found experimentally by
Majerus et al. (1986) and confirmed their hypothesis that a single locus might control the female preference (O'Donald and Majerus, 1985).

\section{DISCUSSION}

Of the studies mentioned above, only Meissner (1907a, b, 1909) and Creed (1975) found no evidence of non-random mating in A. bipunctata. But Creed's sample sizes were small, and they were collected from numerous populations over several years. Consequently, his conclusion that melanic and typical individuals mate at random is unreliable, when compared with the larger surveys, which found good evidence of non-random mating in the form of an excess of melanics in mating pairs. It seems clear, therefore, that there is a widespread apparent mating advantage to melanics.

Muggleton (1979) found evidence that the nonrandom mating is negatively frequency-dependent. $\mathrm{He}$ also concluded that the frequency-dependence is two-sided. This was partly in agreement with Lusis's conclusion that there was non-random mating due to an excess of melanic individuals, but as Muggleton says, "the excess is true only when melanic frequencies are less than 0.5 . When melanic frequencies exceed 0.5 it is the typical morph which is in excess".

But as Brakefield (1984) points out, four key data points in Muggleton's regression analysis consist of only 18 mating pairs. Crucially, these points are those at which melanic frequency is at its highest, that is, when the supposed advantage to typica should be at its greatest. Furthermore, there are few, if any, examples of an excess of typica in any of the samples discussed above. In view of this, the evidence for a frequency-dependent mating advantage to the typica morph becomes weak; and Muggleton's conclusion that there is evidence for frequency-dependent mating is only

Table 10 The results of mating tests on "high preference isofemale lines" (taken from part of table 2, Majerus et al., 1986).

\begin{tabular}{|c|c|c|c|c|c|}
\hline \multirow{2}{*}{$\begin{array}{l}\text { Isofemale } \\
\text { line }\end{array}$} & \multicolumn{2}{|c|}{ Mated males } & \multicolumn{2}{|c|}{ "Total" males } & \multirow{2}{*}{$\begin{array}{l}\text { Estimate of } \\
\text { preference and s.d. }\end{array}$} \\
\hline & $\mathrm{m}$ & $\mathrm{t}$ & $\mathrm{m}$ & $\mathrm{t}$ & \\
\hline Y19 & 272 & 34 & 575 & 575 & $0.801+0.028$ \\
\hline Z37 & 91 & 6 & 240 & 240 & $0.887+0.040$ \\
\hline $\mathrm{Z} 40$ & 102 & 5 & 200 & 200 & $0.918+0.031$ \\
\hline Z35 & 203 & 7 & 385 & 385 & $0.942+0.018$ \\
\hline Total & 668 & 52 & 1400 & 1400 & $0.872+0.015$ \\
\hline
\end{tabular}


true of the advantage to melanics. It follows that there is little evidence for the suggestion of O'Donald and Muggleton (1979) that mating preferences are expressed for both melanic and typical phenotypes in $A$. bipunctata populations.

In fact, our regression analyses suggest that Muggleton's (1979) frequency-dependence results almost entirely from Lusis's (1961) data. There is no evidence of frequency-dependence in either Muggleton's own data, or from Brakefield's large Dutch survey. The only other evidence of a frequency-dependent mating advantage is in the Keele data. So it also seems that there is little evidence in favour of a general frequency-dependent mating advantage to melanics.

Because Lusis's data show clear evidence of frequency-dependence in the mating advantage to melanics, mate choice seems a possible cause. But even if this is true, it cannot be similar to the Keele population which shows a mating advantage to males alone. In fact, most of Lusis's samples show a mating advantage to both melanic males and females. Obviously, if mate choice operates in Lusis's populations then there must be "choosy" males as well as "choosy" females. In consequence, the mating behaviour of $A$. bipunctata is likely to be completely different in these populations, perhaps with the rejection of potential mates by both males and females. Similar comments apply to Brakefield's Dutch data which show neither evidence of frequency-dependence, nor evidence of a melanic mating advantage in favour of males alone, consequently, there is unlikely to be a system of mate choice like that at Keele.

A further difficulty with the Keele data is that although the population at Keele has been studied in detail, there has been no demonstration of a preference for the typical phenotype. There is no complete explanation, therefore, as to how the colour polymorphism in $A$. bipunctata is maintained unless natural selection is presumed to act in favour of the typical phenotype (O'Donald et al., 1984).

An important problem with the data collected from field samples is that there is no direct evidence of the cause of non-random mating, and the sexual preferences postulated by O'Donald and Muggleton (1979) are not the only possible explanation. In fact, if Lusis (1961) is correct and melanics are more active, perhaps because they heat up faster than typicals in sunlight, then there is bound to be a difference in the behaviour of the two phenotypes. This might lead to differential activity during mating or differential habitat selection. Either of these possibilities could cause non- random mating. There could even be observer bias caused by differences in behaviour. For example, in hot weather, melanics might prefer not to rest in exposed conditions where they would be in danger of overheating. But mating melanic females would be shielded from excess heat by the male on top and could behave differently from nonmating individuals. Female habitat preferences are likely to predominate over those of the male during mating because the female carries the male. The weather, the time of day, the type of host plant and the method of observation could influence the observed distribution of phenotypes in mating and non-mating pairs. In any case, it is far from clear that the cause of Lusis's melanic mating advantage is sexual selection through mate choice simply because of an apparent frequency-dependence.

These considerations are also important in the study of the Keele population, not only in the case of data from field samples, but also in respect of experimental data. In the case of the laboratory populations, there was no attempt to control temperature or even the extent to which the experimental populations were exposed to sunlight. So the frequency of mating could have been influenced by environmental conditions. Subsequent experiments (Kearns et al., in preparation) have confirmed that environmental conditions can influence non-random mating in A. bipunctata.

Nevertheless, the results of the Keele study are alone in showing a consistent excess of melanic males in mating pairs. Selection experiments suggested this resulted from a genetic female preference for melanic males. But male competition could also be an important factor in the discrimination between melanic and typical males. Suppose, for example, that melanic males were better at clinging to rejecting females, and as a result, gained more matings. Suppose, in addition, that there was heritable variation in the tendency for females to reject males. Inadvertent selection for "strong rejectors" might give an increased advantage to melanic males, yet the advantage would lie in male competition as well as female choice. Majerus et al. (1982a) initially rejected the possibility of male competition playing a role because they had not observed it in their stocks. But subsequently, we have found it to be quite common in many experiments (Veltman, Kearns and Tomlinson, personal observation).

At the present time there is no single factor which can be invoked to explain the polymorphism in Adalia bipunctata populations. At best, the role of sexual selection through female choice seems confined to a few populations and 
does not appear to be a widespread and general phenomenon.

Acknowledgements This work was supported by a grant from the Science and Engineering Research Council, who also supplied a research studentship (I. P. M. Tomlinson). C. J. Veltman received support as the Ann Horton Visiting Research Fellow in the Sciences, Newnham College; as a British Council Scholar; and with a grant from The Prince and Princess of Wales Science Award. We are grateful to Drs J. Muggleton and M. E. N. Majerus who supplied some of the data.

\section{REFERENCES}

BENGSTON, S-A. AND HAGEN, R. 1975. Polymorphism in the two spot ladybird Adalia bipunctata in Western Norway. Oikos, 26, 328-331.

BISHOP, J. A., COOK, L. M., AND MUGGLETON, J. 1978. The response of two species of moths to industrialisation in north west England. I. Polymorphism for melanism. Phil. Trans. $R$. Soc. Lond. B., 281, 489-515.

BRAKEFIELD, P. M. 1984. Selection along clines in the ladybird Adalia bipunctata in The Netherlands: a general mating advantage to melanics and its consequences. Heredity, 53, 37-49.

BRAKEFIELD, P. M. 1985. Polymorphic Mullerian mimicry and interactions with thermal melanism in ladybirds and a soldier beetle: a hypothesis. Biol. J. Linn. Soc, 26, 243-267.

CREED, E. R. 1966. Geographic variation in the two-spot ladybird in England and Wales. Heredity, 21, 57-72.

CREED, E. R. 1971. Melanism in the two-spot ladybird, Adalia bipunctata, in Great Britain. In Creed, E. R. (ed.) Ecological Genetics and Evolution, Blackwell Scientific Publications, Oxford, pp. 134-151.

CREED, E. R. 1975. Melanism in the two-spot ladybird: the nature and intensity of selection. Proc. R. Soc, Lond. B., $190,135-148$.

KARLIN, S. AND O'DONALD, P. 1978. Some population genetic models combining sexual selection with assortative mating. Heredity, 41, 165-174.

LUS, J. J. 1928. On inheritance of colour and pattern in lady. beetles Adalia bipunctata and Adalia decimpunctata. Izv. Byuro. Genet. Leningrad, 6, 89-163.

LUS, J. J. 1932. An analysis of the dominance phenomenon in the inheritance of the elytra and the pronotum colour in Adalia bipunctata. Trudy Lab. Genet., 9, 135-162.

LUSIS, J. J. 1961. On the biological meaning of colour poly. morphism of ladybeetle Adalia bipunctata L. Latv. Ent., 4, 3-29.
MADER, L. 1926-37. Evidenz der palaarktischen Coccinelliden und ihrer Aberationen, In Wort und Bild. Vienna.

MAJERUS, M. E. N., O'DONALD, P., AND WEIR, J. $1982 a$ Evidence for preferential mating in Adalia bipunctata. Heredity, 49, 37-49.

MAJERUS, M. E. N., O'DONALD. P., AND WEIR, J. 1982b. Female mating preference is genetic. Nature, 300, 521-523.

MAJERUS, M. E. N., ODONALD, P., KEARNS, P. W. E. AND IRELAND, H. 1986. Genetics and evolution of female choice. Nature, 321, 164-167.

MEISSNER, O. $1907 a$. Die relative Haufigkeit der Varietaten von Adalia bipunctata L. in Potsdam (1906). Z. wiss. InsektBiol., 3, 12-20, 39-45.

MEISSNER, O. 1907 b. Die relative Haufigkeit der Varietaten von Adalia bipunctata L. in Potsdam (1907), Z wiss. InsektBiol., 3, 309-313, 334-344, 369-374.

MEISSNER, O. 1909. Die relative Haufigkeit der Varietaten von Adalia bipunctata L. in Potsdam (1908). Z. wiss. InsektBiol., 5, 231-242.

MUGGLETON, J. 1978. Selection against the melanic morphs of Adalia bipunctata (the two spot ladybird: a review and some new data). Heredity, 40, 269-280.

MUGGLETON, J, 1979. Non-random mating in wild populations of polymorphic Adalia bipunctata. Heredity, 42, 57-65.

MUGGLETON, J. 1983. Factors influencing the colour polymorphism in Adalia bipunctata. Ph.D Thesis, University of Nottingham.

MUGGLETON, J.. LONSDALE, D., AND BENHAM, B. R. 1975. Melanism in Adalia bipunctata L. (Col. Coccinellidae) and its relationship to atmospheric pollution. J. appl. Ecol., 12, 451-464.

O'DONALD, P, 1980. Genetic Models of Sexual Selection. Cambridge University Press, Cambridge.

O'DONALD, P., AND MUGGLETON, J. 1979. Melanic polymorphism in ladybirds maintained by sexual selection. Heredity, 43, 143-148.

O'DONALD, P., DERRICK, M., MAJERUS, M, E. N., AND WEIR, J. 1984. Population genetic theory of the assortative mating, sexual selection and natural selection of the two-spot ladybird, Adalia bipunctata. Heredity, 52, 43-61.

O'DONALD, P. AND MAJERUS, M. E. N. 1985. Sexual selection and the evolution of preferential mating in ladybirds. I. Selection for high and low lines of female preference. Heredity, 55, 401-412.

O'DONALD, P. AND MAJERUS, M. E. N. 1988. Frequency-dependent sexual selection. Proc. $R$. Soc. Lond. B., 319, 571-586.

SCALI, V. AND CREED, E. R. 1975. The influence of climate on melanism in the Two-Spot ladybird, Adalia bipunctata, in central Italy. Trans. $R$. ent. Soc. Lond., 127, 163-169.

ROTHSCHILD, M. 1961. Defensive odours and Mullerian mimicry among insects. Trans. $R$. ent. Soc. Lond., 113, 101-122.

TIMOFEef-Ressovsky, N. W. 1940. Zur Analyse des Polymorphismus bei Adalla bipunctata. L. Biol. Zbl., 60, 130 137. 